\title{
Indiana University's First Community-Engaged Research Conference
}

\section{COMMUNITY ENGAGED RESEARCH GROUP}

Community-engaged research is a collaborative process between researcher and community partner resulting in the creation and dissemination of knowledge, contributing both to the well-being of a community and a university discipline. Increasing the awareness and importance of engaged research, the Office of Community Engagement, the Office of the Vice Chancellor for Research and IUPUI's Community Engaged Research Group (CERG) hosted IU's first CommunityEngaged Research Conference.

In November 2019, local community representatives joined in discussions about engaged research with students, staff, faculty, and administrators from IU's Northwest, East, Bloomington, Columbus and IUPUI campuses. Attendees from other universities included Ball State and the University of Michigan.

After welcoming remarks by Dr. Jeff Zaleski, IU Interim Vice Provost for
Research, and Dr. Mary Price, the Director of Faculty Development in the Center for Service and Learning, Dr. Karen Amstutz, IU Health Vice President of Community Health, shared her thoughts about a systematic approach to furthering health access and Adverse Childhood Experiences (ACE) as determinants for health. The luncheon keynote speaker was Carolyn Saxton, Legacy Foundation President, who sparked table conversations about funding community engagement.

A panel of community leaders prompted dialogue and active participation. Patrice Duckett, Executive Director of the Fay Biccard Glick Neighborhood Center, and Sibeko Jywanza, Director of Food Justice at Flanner House, underscored the importance of partnership with the university and contrasted a relationship approach with communities rather than being viewed as a "project." 


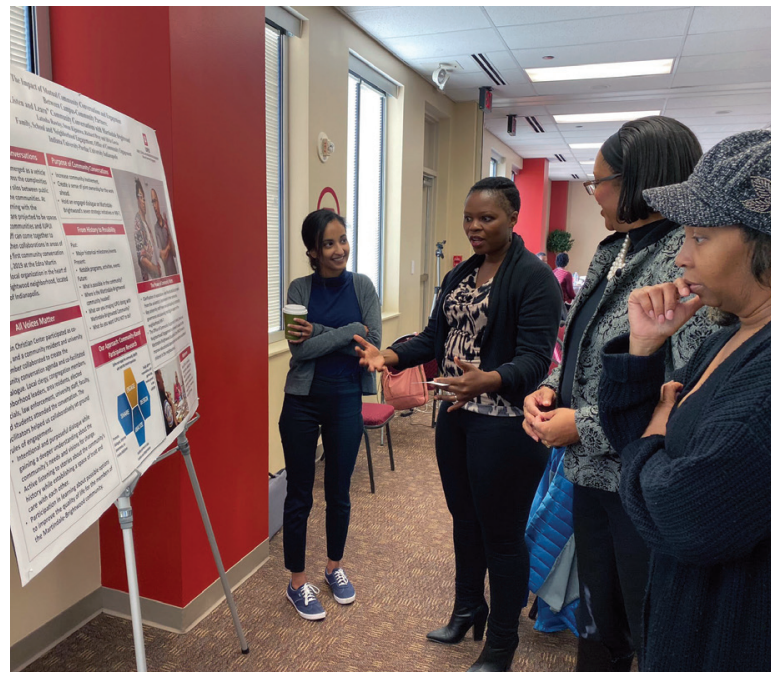

Staff, faculty and students from multiple IU campuses presented their projects in poster presentations. Photo credit: Teresa Francis

Their perspectives highlighted the need to put a community's concerns at the forefront. Patrice and Sibeko both emphasized the importance of forming partnerships with the community: "Feel like you have a connection before you ever have an ask.” For Sibeko, "Relationship building takes time, but authenticity is key in true community engagement." Patrice emphasized the importance of time investments too, "If you haven't taken the time to look at 'how do I build this relationship before I get this research done,' you're coming in with an agenda. And people can smell agendas from a mile away when they've been oppressed for so long!"

Their points suggest the scheduling of an engaged research project may change. As Sibeko stated, “... in order to truly impact a community, ongoing work that is strategically planned out to connect teaching, research and other projects and not just a one-day activity, is necessary." They closed with stressing: "A one-day project won't impact generations of poverty, but building upon the work being done in the community, hearing people's stories, and understanding their perspective can."

In four "Ignite" sessions, IU faculty members described models of their community-engaged

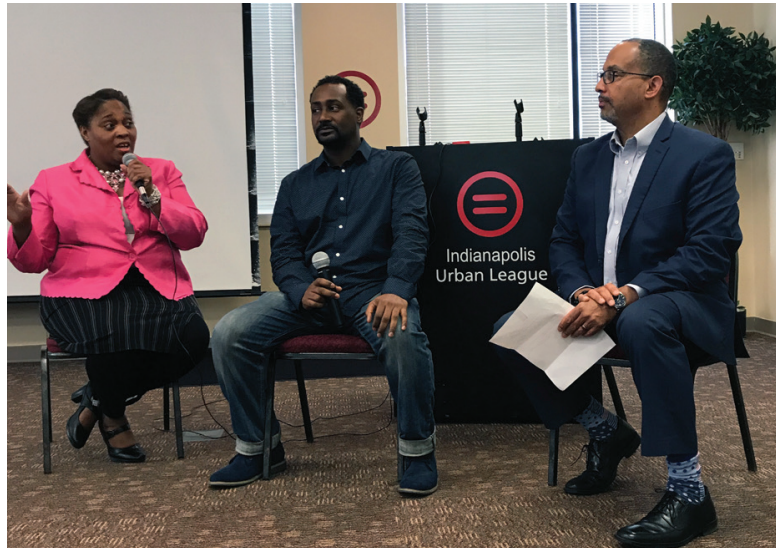

Patrice Duckett, Executive Director of the Fay Biccard Glick Neighborhood Center, and Sibeko Jywanza, Director of Food Justice at Flanner House, spoke during a panel discussion facilitated by Richard Bray, IUPUI Office of Community Engagement Community Partnerships Manager. Photo credit: Annie Goeller

work, moderated by Dr. Silvia Bigatti, Professor in the Fairbanks School of Public Health, and Dr. Brendan Maxcy, Associate Dean for Research in the School of Education.

Director of the IU Southeast Applied Research and Education Center Dr. Melissa Fry's session sparked discussions about using local partnerships to inform decision-making, advocacy and change. And Dr. Armando Soto, Director of Community Engagement for the IU School of Dentistry, in his session kindled ideas and ways to increase community participation in a school-based program while focusing on the issue of informed consent. In her session about how community non-profit, legal and enforcement partnerships reduce recidivism, Carrie Hagan, Director of the Civil Practice Clinic at the IU Robert H. McKinney School of Law, raised a number of critical points. And Ph.D. student Lauren Wendling shared her research about the social circles of individuals with intellectual/developmental disabilities. Two presenters, Wendling and Hagan, are featured in this issue of ENGAGE!

One of the most encouraging and dynamic segments of the conference was facilitated by Kelsie Stringham-Marquis, Research Coordinator at 


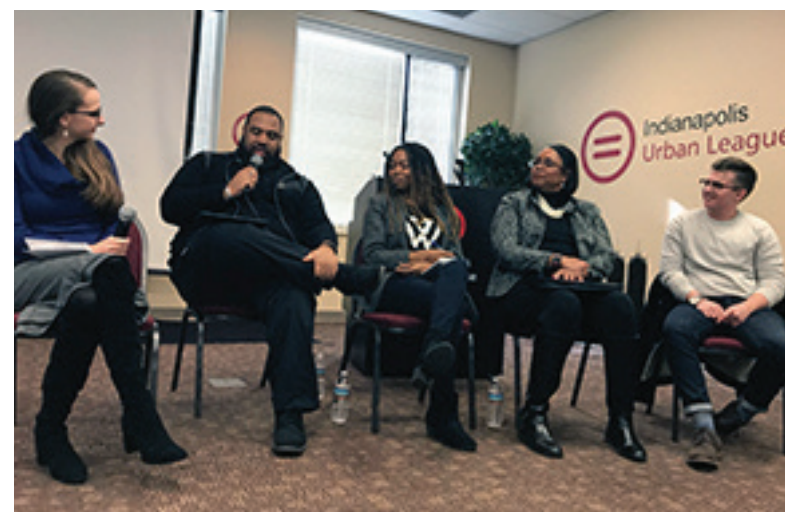

A student panel discussion was led facilitated by Kelsie Stringham-Marquis, Research Coordinator at the Center for Research on Inclusion and Social Policy. The panel included School of Education Urban Education Studies program doctoral student Kevin Hillman; Stacia Murphy, a doctoral student in American Studies; School of Education Urban Education Studies program doctoral student Latosha Rowley; and Weston Jones, a political science and philosophy undergraduate student. Photo credit: Annie Goeller

the Center for Research on Inclusion and Social Policy. Two doctoral students from the School of Education Urban Education Studies program, Kevin Hillman and Latosha Rowley, served on a panel with Stacia Murphy, a doctoral student in American Studies, and Weston Jones, a political science and philosophy undergraduate student.

They engaged the audience in a lively dialogue addressing issues of preparation, challenges, and experiences with community-engaged research, the types of research and scholarship they would like to be involved in through their future careers. The students talked about the importance of community-based participatory research in their professional preparation. They also suggested ways the university could better incorporate community engagement into their studies.

Weston recognized the value of community-based participatory research and the more holistic view it gives to a project, but also noted that finding social science research opportunities as a student in the School of Liberal Arts was difficult. Stacia suggested the university develop curriculum around the idea of building relationships with communities as part of student preparation for engaged research. Kevin noted that collaborating with the community should be a key focus of the university, as it relates to student interests. While Latosha shared her experience in a community center, where she quickly learned how important relationship building is particularly as a representative of the university. She also noted "how tough navigating those relationships can be.”

Conference attendees also were able to hear about specific community-engaged projects being done by IU staff and faculty through poster presentations, and strongly recommended hosting the conference again, and perhaps even lengthening it to more days.

This conference and its intriguing discussions launched what we anticipate will continue - and further develop-IU's commitment to community-engaged and community-based participatory research. Those who attended the conference identified other issues they would like to cover in the future, including capacity building, inclusion and equity, identifying funding and working through challenges. With this positive and constructive feedback, we are planning our next conference, and look forward to growing this unique opportunity to include more members of the university and the community.

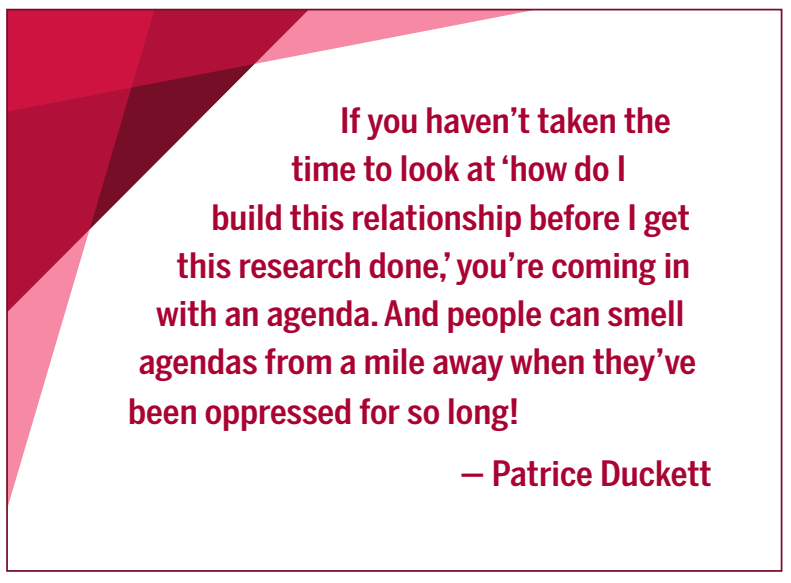



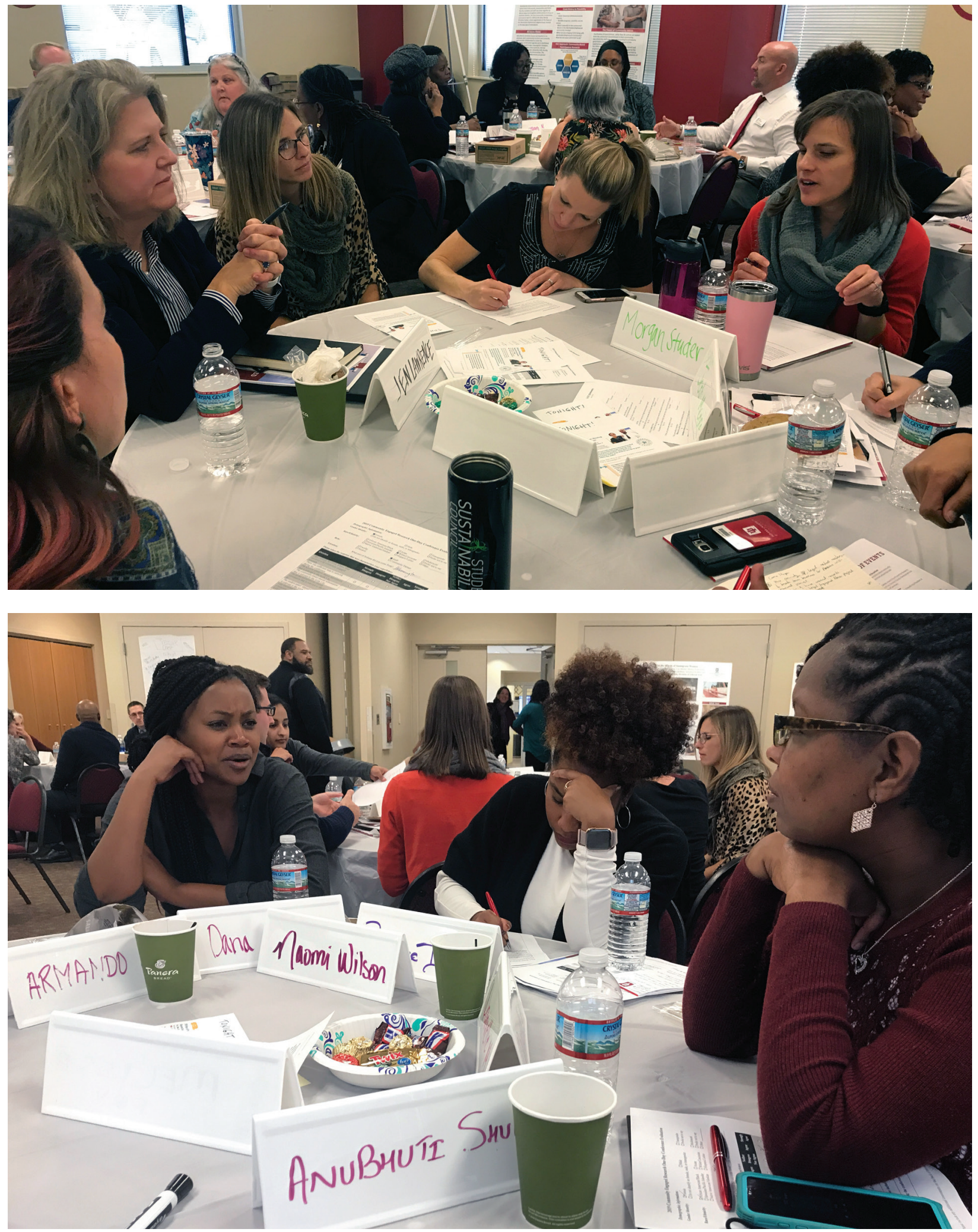

Conference attendees worked together in group discussions centered on community engagement.

Photo credit: Annie Goeller 